\title{
Preference of Bancassurance
}

\author{
Dr. V. Sreedevi ${ }^{1}$, P.Lovelin Auguskani ${ }^{2}$ \\ 1.Research Guide, Manonmaniam Sundaranar University, India \\ 2.Research Scholar, Manonmaniam Sundaranar University,India
}

\begin{abstract}
In India ever since the espousing of financial reforms following the recommendations of Fist Narasimhan committee, the contemporary financial landscape has been reshaped. Banks, in particular, stride into several new areas and offer innovative products, viz., merchant banking, lease and term finance etc. Today banks have become far more diversified than ever before. Therefore banks are entering into the world of bancassurance - an innovative financial product as required by bank customers.
\end{abstract}

Keywords: Bank, Bancassurance, Customer Preference, Insurance

\section{Introduction}

Over the last few decades, the liberalization and deregulation of the financial sector have drawn the worlds of the banking and insurance closer together. Inter-bank competition has thickened and banks face increasing competition from non-banking financial institutions and the financial markets. The business of banking around the world is being changed due to integration of global financial market, development of new technologies, universalization of banking operations and diversification in non-banking activities. The liberalization of financial sector in India is exposing Indian banks to a new economic environment that is characterized by increased competition and new regulatory requirements. As a result, there is transformation in every sphere of activities of the banks in India, especially in their governance, nature of business, style of functioning and delivery mechanisms.

The accelerated process of globalization of financial markets and integration of Indian financial sector with rest of the world has enhanced both opportunities and challenges. Change is the only constant factor in this world; banking is not an exception to this in the competitive world. Earlier our economy was supply based and was an era of seller's market. But at present the situation has changed and has entered into an era of buyer's market. As the economy grows, not only does it demand stronger and vibrant financial sector but also necessitates to provide with more sophisticated and variety of financial products and services. India is considered as one of the fast developing economies among the emerging market economies, the financial sector has also grown much vibrant with the financial reforms.

\subsection{Scope of Bancassurance}

India, with a democratic government and a population of more than one billion has a savings rate of around 23 percent, of which deposits with the bank constitute more than 40 percent, insurance fund constitute 14.9 percent and provident / pension fund accounts for 13 percent of the financial savings as recorded for the financial year 2004-2005. This shows trend away from deposits and towards insurance products and mutual funds where the return is usually higher than the return on traditional deposit accounts. This shift in investment has led to reduction in the share of personal savings held as deposits. With the shift in customer preferences from deposits to investments, intense competition etc, the bank's profit margin has started to decline. There is an urgent need for the banking industry to find alternative ways to generate income and to retain the customers by providing value added services under one roof and to stream line the savings into insurance, wherein Bancassurance is the best channel.

By successfully mining their customer data bases, leveraging their reputation and distribution systems (branch, phone and mail) to make appointments and utilizing their sales techniques, banks can make Bancassurance a profitable service.

\subsection{Importance of the Study}

Bancassurance has a tremendous acceptance and growth across the nation. Securities business made an automatic extension to bank and insurance. This integration will be a step further towards universal banking and would leverage the efficiencies developed by alliance of banks and insurance companies. This will be useful for the customers who want to get a one stop shop for all financial products. Hence banks themselves transform to a wholesome entity. This has to be integrated with international banking and other IT infrastructure.

Insurance is the fast growing industry and has a significant contribution in socio-economic development of the economy. Huge untapped Indian market gives an opportunity and challenge to the insurance company. The success of any insurance business depends on the distribution channel. The rising market 
competition and demand for innovative and need based products by customers have compelled insurance companies to look for alternative cost effective distribution channels. The integration of insurance with banks will contribute more to economy.

The focus of this study is to know the level of customer awareness, satisfaction, preferences and perception towards buying insurance products from banks.

\section{Review Of Literature}

The concept of Bancassurance was originated in France and first Bancassurance started in operation way back in 1970s. It is a phenomenon where insurance products are offered through the distribution channels of the banking services along with a complete range of banking investment products and services.

Bancassurance, i.e., Bank + Assurance, refers to banks selling the insurance products. Both banking and insurance product and services are provided by one corporate entity or by banking company with collaboration of any particular company. Bancassurance also known as allfinanz describes a package of financial services that can fulfill both banking and insurance needs at the same time. The term first appeared in France in 1980, to define the sale of insurance products through banks distribution channels (SCOR 2003) ${ }^{1}$

Graham Morris $(2001)^{2}$ opined that though Bancassurance in the Indian environment is at a very early stage of development, it is new and untried, and the potential is undoubtedly there. Though there may be some initial stumbling blocks, for example, clarity of legislation but the critical factor will be the selection of the right model and practical approach. Success will be likely to come more easily through the strategic alliances and cross share holdings. Use of right technology and awareness and education of the banking industry are other critical success factors for the insurance industry.

While providing bancassurance model for India it is suggested to start with simple product (accident/health) through direct marketing. This will help update customer information, segment the customer database for more effective marketing and achieve profits with low investment/risk. Total commitment at top level of life insurer and bank is also important for the success of Bancassurance along with the fact that bank appreciates and acts on the 'Difficult' selling process of life insurance products (Allen J pathmarajah 2003) . $^{3}$.

There is no one magic formula to Bancassurance. The model chosen has to be consistent to the overriding strategies and objectives for this particular business. Execution excellence is the key to success and together partners must extremely work hard at understanding each other, while developing common objectives and being truly committed to achieving a mutually desired and acceptable out come (Mc. Dermott and Saunders $2003)^{4}$.

The concept of Bancassurance appears to be gaining ground quite rapidly both through commission based arrangements and joint ventures between banks and insurance companies. However it is cautioned that tying up with a bank might prove counter productive to the objective of brand equity for the insurance firms (Barua 2004) . $^{5}$

Bancassurance requires having appropriate awareness among bank employees and ensuring that they understand its mechanism. This involves a change of mindset and developing appropriate system at the bank level. India had very little experience in this field and there were no role models. Some companies have global experience in this field such as AVIVA insurance which did not face any problem. However there is a need to build congruence of interest between insurance selling and retail banking unit. (Bhat and Dixit 2005) ${ }^{6}$.

In the Indian context it has been found that, "business per employee" is negatively correlated with bancassurance variable at a significant level of 5 percent, hence for banks when the business is low, it is likely to be attracted to improve productivity by adding bancassurance in their portfolios. Asset performance was also negatively correlated with the non performing assets. However, the association was weaker (only significant at 10 percent). For insurance companies, non-performing assets of a bank will act as brake on the bank or insurance company tie-up for insurance distribution (Tapen sinha 2005). ${ }^{7}$.

Bancassurance is selling insurance products by banks through their distribution channels. It has become one of the major Para banking activities of the banks. If marketing of insurance products by banks is done efficiently and ethically, than it insures a win-win situation for all parties concerned, the bank, the insurance company as well as the customer. There is a large potential and future development of bancassurance in India and many insurers finding it as a attractive and profitable form of distribution channel for distribution of their products (Anuja Banerjee 2009) ${ }^{8}$.

The cultural difference between banks and insurance companies could pose a major challenge to the growth of bancassurance. Large customer database and people trust on bank is the main opportunity for banks as a distribution channel for insurance companies. (Kumar 2006) ${ }^{9}$.

Insurance is the backbone of country's risk management system and influences the growth of an economy in several ways. Penetration of insurance largely depends on availability of insurance products, insurance awareness and quality of services. The future growth of this sector will depend on how effectively the 
insurance firms are meeting the expectations of their customers and able to change the perceptions of the Indian consumers and make them become aware of insurable risks. (Krishnamurthy S 2005) ${ }^{10}$.

The intermediaries play an important role in the success of insurance business. Selling of life insurance products largely depends on the skill and efficiency of the distributor. The role of agent is very vital as compared to other forms of market channels like brokers, corporate agent's bancassurance, etc. Bancassurance is emerging as a new form of distribution channel where banks performed role of intermediary and sell policy directly to the customers (Jay Narayanan 2008) ${ }^{11}$.

\section{Research Methodology}

The study is an empirical and descriptive based study on customer preferences towards Bancassurance. The researchers have selected IOB bank customers for the study. The primary data is collected for the study through a well designed structural questionnaire and discussion with bank customers (Delphi technique) with or without life insurance policy. Sample size has 100 respondents who were identified randomly through convenience sampling. Secondary data is collected from various publications, Journal, Insurance Magazines, Official websites, Annual reports and News papers.

\subsection{Objectives}

1. To study the awareness of customers on Bancassurance.

2. To study the customer perception and analyze the factors affecting buying of the insurance products from Banks.

3. To make SWOT analysis of Bancassurance.

\section{Data Analysis And Interpretation}

A survey was conducted in Kanyakumari District of Tamilnadu on 100 respondents of bank customers who did regular banking transactions and also had an insurance policy. A questionnaire was designed and survey was conducted to understand penetration of bancassurance in Indian market, preferences and perception of customers towards buying life insurance policy from bancassurance.

Customer awareness refers to a buyer's knowledge of a particular product or services which give more benefit to the buyer from what he buys.

Table No. 1.1Awareness level

\begin{tabular}{|c|c|c|}
\hline Responses & No. of respondents & Percentage \\
\hline Yes & 40 & 40 \\
\hline No & 60 & 60 \\
\hline Total & $\mathbf{1 0 0}$ & $\mathbf{1 0 0}$ \\
\hline
\end{tabular}

The above table reveals that 60 percent of the respondents are not aware of the concept bancassurance and 40 percent respondents are aware of the new form of Bancassurance. There is an urgent need to spread awareness among the customers. 60 percent of the respondents were aware of the fact that their banks are providing bancassurance services. They also knew with which insurance company their banks has tie-up and besides the various insurance products provided by their banks.

Among the people surveyed, there were only 38 percentage people who had taken insurance policy from their respective banks. Remaining 62 percentages of respondents have not preferred to take a policy from their banks. It is a shown in the following tables.

Table No. 1.2 Mode If Insurance Policy

\begin{tabular}{|c|c|c|}
\hline Responses & No. of respondents & Percentage \\
\hline Insurance policy taken through Banks & 38 & 38 \\
\hline Others & 62 & 62 \\
\hline TOTAL & $\mathbf{1 0 0}$ & $\mathbf{1 0 0}$ \\
\hline
\end{tabular}

Table No. 1.3 Kind of Insurance Policy Taken

\begin{tabular}{|c|c|c|}
\hline Type of Insurance Policy & No. of respondents & Percentage \\
\hline Deposit based & 19 & 62 \\
\hline Loan based & 62 & 8 \\
\hline Life Insurance & 8 & 11 \\
\hline Others & 11 & $\mathbf{1 0 0}$ \\
\hline
\end{tabular}

Maximum number of insurance policy was taken for loan purposes. It was either car insurance or home insurance. 62 percentage of people said that they have taken loan based insurance policy. 19 percentage of 
people have taken insurance which are deposited based on the part of the deposit scheme. Only 8 percentage of the respondents have taken insurance policy from their banks.

There are different reasons for buying life insurance policy and it depends on the needs, income and other influencing factors of individuals. Some buy for tax benefits and others for security and so on.

Table No.1.4 Reasons for Buying Insurance Policy

\begin{tabular}{|c|c|c|}
\hline Reasons & No. of respondents & Percentage \\
\hline As savings & 16 & 36 \\
\hline As tax saving & 38 & 25 \\
\hline As security & 25 & 21 \\
\hline Return & 21 & $\mathbf{1 0 0}$ \\
\hline TOTAL & $\mathbf{1 0 0}$ & Po \\
\hline
\end{tabular}

It has been depicted in the Table 1.4 that 38 percentages of respondents purchase life policy for tax benefits followed by 25 percentage who buy for security 21 percentage for return and 16 percentage for savings purpose.

Table No. 1.5 Advantages Of Buying Policy Through Banks

\begin{tabular}{|c|c|c|}
\hline Advantages & No. of respondents & Percentage \\
\hline Trust and loyalty & 46 & 26 \\
\hline Easy accessibility & 20 & 14 \\
\hline Expert's advice & 14 & 20 \\
\hline Convenience & 20 & $\mathbf{1 0 0}$ \\
\hline TOTAL & $\mathbf{1 0 0}$ & \\
\hline
\end{tabular}

Table No. 1.5 shows the advantages of buying policy through banks. A majority of the respondents (46 percentages) have trust and loyalty on banks as compared to insurance companies, 20 percentage of respondents buy policy through banks for easy accessibility and 14 percentage respondents think that they easily get expert advice on investment plans and the remaining (20 percentages) feel that it is more convenient to buy policy from bank.

Table No.1.6 Choice Of Insurance Distribution Channel

\begin{tabular}{|c|c|c|}
\hline Distribution Channel & No. of respondents & Percentage \\
\hline Agents & 45 & 45 \\
\hline Brokers & 12 & 12 \\
\hline Banks & 23 & 23 \\
\hline Insurance companies & 20 & $\mathbf{1 0 0}$ \\
\hline TOTAL & $\mathbf{1 0 0}$ & $\mathbf{1 0 0}$ \\
\hline
\end{tabular}

Of the respondents 45 percentage preferred agents because they provide personalized services. 23 percentage choose to buy insurance from banks because of the brand name and their trust on banks only 12 percentage like to buy insurance from brokers.

Table No. 1.7 Familiarity With Various Types Of Policies Offered By Bank

\begin{tabular}{|c|c|c|}
\hline Response & No. of respondents & Percentage \\
\hline Yes & 22 & 22 \\
\hline No & 53 & 53 \\
\hline No response & 25 & 25 \\
\hline TOTAL & $\mathbf{1 0 0}$ & $\mathbf{1 0 0}$ \\
\hline
\end{tabular}

A variety of products are offered by life insurance companies through banks. Due to the lack of awareness, majority of the customers are not familiar with the types of policies sold by the banks (53percentages) 22 percentage of the respondents are familiar with the policy and 25 percentage have not given any responses.

Table No.1.8 Satisfaction With Bank Services

\begin{tabular}{|c|c|c|}
\hline Response & No. of respondents & Percentage \\
\hline Highly Satisfied & 15 & 15 \\
\hline satisfied & 18 & 18 \\
\hline Moderately satisfied & 37 & 37 \\
\hline Dissatisfied & 22 & 22 \\
\hline Highly dissatisfied & 8 & 8 \\
\hline TOTAL & $\mathbf{1 0 0}$ & $\mathbf{1 0 0}$ \\
\hline
\end{tabular}

Today, customer satisfaction is the motto of every organization. Bank provides various services to the customers. Both pre and after sales services are important in service based industry as their business mainly depends on the satisfaction of the customers. Majority of the respondents (37percentages) are moderately satisfied with the bank services. The respondents of 15 and 18 percentages are highly satisfied. 22 and 8 
percentage respondents are dissatisfied and highly dissatisfied respectively with the services provided by banks. Banks need to improve quality of services to get more customers for business and to retain them in the long run.

Table No. 1.9 Performance in Bancassurance

\begin{tabular}{|c|c|c|}
\hline Response & No. of respondents & Percentage \\
\hline Public sector Banks & 18 & 18 \\
\hline Private sector Banks & 50 & 50 \\
\hline Foreign Banks & 32 & 32 \\
\hline TOTAL & $\mathbf{1 0 0}$ & $\mathbf{1 0 0}$ \\
\hline
\end{tabular}

50 percentages of the respondent opined that private sector banks would perform better in bancassurance, because of their aggressive selling policies besides they provide quality services to the customers. 32 percentages of the respondents felt that with the aggressive selling strategies and proper management, foreign banks would perform better. Public sector banks were given the least choice because of their lazy approach to work.

Many people are interested to buy life policy but they have delayed it for future. The future planning of investment in life insurance policy will help in knowing the actual status of the industry. Majority of the respondents (28 percentages) are not in favor of buying policy in future and 39 percentages respondents are willing to buy policy in future and the remaining 33 percentages have not taken any future buying decisions.

Table No. 1.10 Future Planning Towards Investment in Life Insurance

\begin{tabular}{|c|c|c|}
\hline Responses & No. of respondents & Percentage \\
\hline Yes & 39 & 39 \\
\hline No & 28 & 28 \\
\hline Not decided & 33 & 33 \\
\hline TOTAL & $\mathbf{1 0 0}$ & $\mathbf{1 0 0}$ \\
\hline
\end{tabular}

95 percentages of people believe that banacassurance has a very bright future because there is an immense potential for the insurance industry in India. But 5 percentage respondents believe that because of the emergence of the new technology such as ATMs, internet banking, etc, the banks will soon go virtual so there is not much scope for it.

\subsection{Findings}

- A large number of respondents (60 percentages) are not aware of the concept of Banacassurance. Hence there is a need to spread awareness among the general public.

- It has also been found that the banks have various opportunities to cross sell insurance products. The insurance companies also have the opportunity to take advantage of the bank's network and other avenues. It is also seen that customers have a lot of trust on the banks and because of that trust the customers will take the insurance products from banks (38 percentages).

- Majority of the insurance was taken for loan purposes (62 percentages)

- A majority of the respondents (38 percentages) are buying life insurance policy for tax benefits. Hence insurance company should communicate right message to the people and motivate people for buying policy for life protection.

- Trust and Loyalty is the main reason for which most of the respondents (46 percentages) are buying life policy through banks. People have more faith on bank when compared to other modes of distribution.

- A majority of the respondents (45 percentages) are buying life insurance policy from agents than banks (23 percentages). Hence agents are more acceptable and a popular distribution channel in Indian insurance industry.

- Most of the respondents (53 percentages) are not familiar with the type of policy offered by banks.

- Most of the respondents (37 percentages) are only moderately satisfied with various services of banks. Therefore banks need to improve the quality of its service to get more customers and higher satisfaction.

- Only 39 percentage respondents are planning to take life insurance policy in future. It shows that the customers preferred to take other investment options than insurance.

\subsection{Suggestions}

- The insurance companies need to design products specifically for distributing through banks.

- Arrange various awareness programmes and other measures to spread awareness on the concepts and benefits of Banacassurance among the customers.

- Banks may also offer after sales services and it could be more aggressive in selling insurance products.

- $\quad$ Performance appraisal and sales training needed to be emphasized for improved performance. 
- Bank may improve the quality of services to rebuild their image.

- Offer best product to the customers at the least cost.

- Banks may also do the settlement of claims which will increase the trust and reliability of customers on the banks.

- Attractive incentives and proper motivation may be given to the marketing personnel of banks to sell insurance products in an effective way.

- Insurance companies need to come up with simple IT solutions to enable the bank staff to record sales details at the branch itself.

\subsection{SWOT Analysis}

\section{Banacassurance in India - A SWOT Analysis}

\begin{tabular}{|l|l|}
\hline \multicolumn{1}{|c|}{ Strengths } & \multicolumn{1}{|c|}{ Weaknesses } \\
\hline Bank credibility and sustained image & $\begin{array}{l}\text { Information Technology (IT) culture is missing completely and } \\
\text { internet connections are also not properly provided to the staff. }\end{array}$ \\
\hline Wide network of Banks (branches even in remotest areas) & $\begin{array}{l}\text { The visits in urban or metro branches are going to be fewer } \\
\text { because of ATM's and e-banking. No time to have a discussion on } \\
\text { long term durable purchase like insurance across the counter. }\end{array}$ \\
\hline Large untapped population of India & Lack of personalized services. \\
\hline Product development and innovation by insurance companies & Low consumer awareness. \\
\hline Cheaper mode of distribution channel. & Inflexibility of products \\
\hline Large middle class households of distribution channel. & Heavy premiums \\
\hline \multicolumn{1}{|c|}{ Opportunities } & Considered as an investment not protection tool. \\
\hline Majority of the population is un insured & Threats \\
\hline Trust and loyalty of the people on banks & $\begin{array}{l}\text { Lack of experience in selling insurance products (lack of sales } \\
\text { culture in bank) }\end{array}$ \\
\hline Introduction of Information Communication Technology (ICT). & Additional stress to bank employees. \\
\hline Speedy customer service & Not suitable for complex products \\
\hline Contributing towards Return on Investment (ROI) & Availability of various investment options. \\
\hline
\end{tabular}

\section{Conclusion}

Economic growth has strongly supported the expansion of the middle income class in most of the Asian Countries and now it is India's turn. Experience reveals that at the initial growing stage of economy, the primary strongly felt financial need for the other non - banking financial products including insurance, derivative, etc. Moreover, India already has more than 200 million middleclass population coupled with vast banking network with a large depositor's base with that there is a greater scope for bancassurance in India.

\section{Referrences}

[1] Bancassurance across the globe - meets with very mixed response Scor Technical News letter February 2003 France.

[2] Graham Morris, "Bancassurance in the Indian Environment, The first Indian International Bancassurance conference, Mumbai November,2001

[3] Pathmrajab J. Allen ,'Indian Insurnace Sector: Bancassurance Achievements and Prospects' $8^{\text {th }}$ conference on Insurance 2003.

[4] Bence Dermott Saunders, and Mark, 'Bancassurance : Doing it Right', Asia Insurance Review,. April 2003.

[5] Barua, Abheek, "Bancassurance : New concept cut chair, up fast in India", The chartered Accountant, June 2004, PP 13481351.

[6] Bhat, Ramesh and M.R Dixit, "Bancassurance : Exploiting an opportunity with partnerships", vikalpa, vol 30, No.3 Jul-Sept. PP $111-115$

[7] Tapen, Sinha, Bancassurance in India : who is Typing the knot and why(2005).

[8] Anuja Banerjee, "Bancassurance : a major para - banking activity", ICFAI Insurance chronide magazine(April 2009).

[9] Kumar, R , "Bancassurance - opportunities and challenges in India", Bancassurance Trends and opportunities, First Edition, Hyderabad, ICFAI publication 2006. PP 176-178.

[10] Krishnamurty.S, Jhuvai, Nani, Bakshi .S, Insurance Industry in India : Structure, performance and future challenge, vikalpa, HMA volume 30, (July-Sep.2005), No. 3 pp 93-95.

[11] Narayanan Jay, "Role of intermediaries in Life Insurance" IRDA Journal,(Oct. 2008), vol. VI No. 10. 